\title{
Academic Self-Concept and Academic Performance of College of Education Students
}

\author{
Samuel Obed Amoah ${ }^{1 *} \quad$ Henry Yaw Acheampong ${ }^{1} \quad$ Elizabeth Adoma Sefah ${ }^{2}$ \\ Francis Britwum ${ }^{1} \quad$ Edwin Adjei ${ }^{3}$ \\ 1. Department of Education Studies, St. Monica's College of Education, P. O Box 250, Mampong-Ashanti, \\ Ghana \\ 2. Department of Education and Psychology, University of Cape Coast, PMB Cape Coast, Ghana \\ 3. Department of Education Studies, SDA College of Education Agona, P. O Box 29 Agona-Ashanti, Ghana
}

\begin{abstract}
The study examined academic self-concepts (ASC) and academic performance of College of Education students in Ghana. The descriptive survey design was adopted using a sample of 229 students. An original ASC scale by Liu \&Wang (2005) was adopted and used for the study. Independent sample T-test and multiple linear regression were the tools used in testing the hypotheses. The findings of the study showed that there is no statistically significant gender difference in ASC of College of Education students. The study further revealed that ASC did not predict academic performance of College of Education students. The study recommends that, stakeholders such as teachers and parents must consider a variety of factors that can influence the development of a healthy ASC and must also encourage, monitor, and supervise students to put in some effort in their studies because effort promotes academic performance. The study again, recommends that academicians should hold workshops and seminars to students in developing a stronger self-concept so that they can improve their abilities and lead a successful life in the future. Students with low ASC may benefit from counseling sessions in order to enhance their academic standing. It may be suggested that curriculum designers pay attention to the relevance of selfconcept and create courses that will encourage students to think critically and thoroughly in order to improve their self-concept.
\end{abstract}

Keywords: key words, academic self-concepts and academic performance

DOI: $10.7176 / \mathrm{JEP} / 12-24-06$

Publication date:August $31^{\text {st }} 2021$

\section{Introduction}

For a variety of factors, academic success is a significant predictor of a student's transition. Students who perform well in school are more likely to graduate from high school and attend and complete college than their peers who perform poorly (Schnepf, 2006). Test scores in Colleges of Education predicts future performance in the work market in terms of higher pay. (Joppke \& Morawska, 2003). Lower levels of education and skills are linked to lower levels of economic performance, including a higher probability of poverty and reliance on government assistance (Eurydice, 2004). Thus, a student's academic performance is important because it contributes to their future success. Students' academic success may be influenced by a variety of factors, including their cultural experience with the educational system, (Deyhle \& Swisher, 1997), linguistic proficiency (Lansford, Deater-Deckard, \& Bornstein, 2007), socioeconomic resources (Fuligni \& Fuligni, 2007), parental involvement in education (Fuligni, 1997), parental aspirations (Taylor \& Krahn, 2005), family obligation (Fuligni, 2001), academic self-concept (ASC) (Cokley \& Patel, 2007), and academic motivation (Fuligni, 2001).

In recent years, the study of ASC has sparked a surge of interest by psychologist. Given that it has been approached from various theoretical viewpoints, it is difficult to find a unanimous, agreed description of the term self-concept, despite the abundance of studies devoted to it. Nonetheless, all of the writers accept that the word "self-concept" has several dimensions. The set of characteristics, strengths, virtues and shortcomings, capacities and limitations, beliefs and relationships that a person know to be representative of himself or herself and that he or she perceives as data concerning his or her identity is known as self-concept (Marsh \& Seeshing, 1997). ASC is thought to have many dimensions, regions, or facets, some of which appear to be a collection of attitudes, beliefs, and perceptions held by students about their academic skill sets and performance (Lent, Brown, \& Gore, 1997). According to Cokley (2000a), ASC include a comparative dimension in which students compared their academic attitudes and skills to those of other students. Academic performance has been shown to be closely related to ASC (Marsh, 1990). ASC has previously been considered a significant psychological construct in the context of education (Marsh, Trautwein, Ludtke, Koller, \& Baumert, 2005) since "it has been found to be both a cause and effect on performance" (Cokley, 2007, p. 2). Research indicates that students with a higher ASC performed better academically than students with lower ASC (Marsh, 1990).

Marsh and Parker (1984) also believe that students' ASC is shaped by a mechanism of social comparison, which occurs when students equate their abilities to those of others. The tertiary education level, particularly in the Colleges of Education, is usually a time of developmental transition during which a person passes from 
childhood to adolescence. During this period of transformation, students are subjected to a great deal of psychological and sociological strain at school. They face psychological maturation, cognitive shifts, social and parental expectations sifting, contradictory position demands, difficulty in relationships with parents and peers, school and subject selection, and school climate adjustment. (Block \& Robins, 1993). In this context it becomes imperative to examine impact of ASC on academic performance of College of Education students in Ghana.

\section{Statement of the Problem}

Various studies have attempted to understand whether an increase in ASC leads to an increase in academic performance, according to the researchers. (Green, Nelson, Martin \& Marsh, 2006). A variety of studies have looked into the causal relationships between self-concepts and academic performance, according to the authors. According to Green, Nelson, Martin and Marsh (2006), there has been research into the relationship between self-concept and academic performance, with only few studies examining the effects of self-concepts in predicting academic performance of students. In Ghana, little is known about the impact of ASC on students' academic performance in Ghanaian Colleges of Education, but it appears that poor ASC may be related to poor academic performance (WAEC, 2012; Saani, 2012). Hence, there is the need to examine the impact of ASC on academic performance of College of Education students.

\section{Research Hypotheses}

1. H0: ASC will predict academic performance of College of Education students.

H1: ASC will not predict academic performance of College of Education students.

2. H0: There is no statistical significance gender difference in ASC of College of Education students.

H1: There is a statistical significance gender difference in ASC of College of Education students.

\section{Literature Review}

\subsection{Multidimensional Model of Self-Concept}

Shavelson, Hubner, and Stanton (1976) model divides self-concept into academic (e.g., math, linguistic, science) and non-academic (e.g., social, physical, emotional) components, implying that self-concept is multifaceted, hierarchically ordered, and becomes increasingly differentiated with age. Individuals' perception of self is formed in response to their perceptions of others' reactions toward them, according to Shavelson Hubner and Stanton (1976) model, and these perceptions of self and subsequent self-concepts are based on a hierarchy. As a result, ASC is most strongly correlated with self-concept, followed by subject-specific self-concept, and subjectspecific success is least strongly correlated with self-concept. Although self-concept researchers have largely endorsed the multidimensional, hierarchical model of self-concept, the relationship between ASC domains and academic performance cannot be fully understood if researchers rely solely on global self-concept estimates. (Marsh \& Hau, 2004).

Within the multidimensional paradigm of self-concept, math and verbal self-concepts have been virtually uncorrelated. (Marsh, 1986). Since an adolescent's math and verbal self-concepts may vary greatly, having a high math self-concept does not always imply having a high verbal self-concept. Marsh $(1986,1990)$ created the Internal/External frames of reference model (I/E model) to clarify the discrepancy between virtually uncorrelated math and verbal self-concept scores because this result contradicts the Shavelson model. Students measure their own success in any school subject in comparison to their performance in other school subjects within the internal frame of reference. As a result, people creates a hierarchy of self-concept based on his or her ability in all other school subjects. Students measure their self-perceived success in any given school subject to the perceived performance of other students in the same school within the external frame of reference. Students' math and verbal self-concepts are based on this external reference (Areepattamannil \& Freeman, 2008).

\subsection{Academic Self-Concepts and Academic Performance}

The direction of the causal relationship between ASC and academic performance has been investigated by studies. According to Marsh, Trautwein, Ludtke, Koller and Baumert (2005), improving students' academic performance without improving their self-concept in similar academic domains would most likely to result in only short-term gains. Marsh, et al. (2005) made this suggestion, which Liu (2009) agreed with. Students who have less satisfactory academic results, according to Liu (2009), can develop less positive academic trust, which can contribute to a lower ASC. Students with a negative ASC, on the other hand, are more likely to lack learning motivation, which may lead to poor academic success. As a result, according to Liu (2009), ASC and academic performance appear to influence and decide one another. This assertion by Liu (2009) coincides with Marsh and Craven's (1997) suggestion that prior ASC affects subsequent academic performance.

In a longitudinal study of 697 elementary pupils, Helmke and vanAken (1995) looked at the causal ordering of self-concept and academic achievement. Grades or test results were used to judge achievement. These were compared to see if the causal ordering of self-concept and academic achievement differed. The findings revealed 
a reciprocal, causal relationship between children' self-concept and academic achievement, "implying that selfconcept in primary school acts both as cause and as effect," according to the researchers (Helmke \& vanAken, 1995, p. 633).

In a study conducted by Guay, Ratelle, Soy and Litalien (2010), students who considered themselves to be academically competent received higher grades because their ASC contributed to them becoming more autonomously motivated at school. Skaalvik, Valas and Sletta (1994) suggested that students with a high ASC might be more concerned with outperforming their peers academically. According to Skaalvik, Valas and Sletta (1994), this orientation predicts a positive relationship between ASC and success goals. This suggests that students who have a positive ASC are more likely to focus on mastering their school work.

\subsection{Gender and Academic Self-Concepts}

Previous research has looked into the connection between gender and ASC. Male students showed higher levels of ASC than female students in numerous studies (Baran \& Maskan, 2011; Cooper, Krieg, \& Brownell, 2018; Karasakaloğlu \& Saracaloğlu, 2009). Marsh (1989) discovered statistically significance but minor gender variations in different aspects of ASC, some of which favoured girls but others which favoured boys more. The most significant difference was in ASC, with males showing higher ASC than females. (Aronson 2002; Ireson \& Hallam, 2009; Marsh 1989). Males have a stronger association (significance of difference not often assessed) with self-concept and school accomplishment than girls, according to several researchers (Fink, 1962; Jones \& Grieneeks, 1970). Others claim that there are strong relationships between males and females, but not vice versa (Epps, 1969; Kubiniec, 1970; Shaw \& Alves, 1963).

In contrast, Jones and Strowig (1968) found that females' self-concepts had a better predictive potential (higher beta weight) for achievement than males. Females have a stronger association between self-concept and grade point average than males, according to Binder, Jones, and Strowig (1970). Pehlivan (2006), on the other hand, found that female students had higher levels of ASC than male students in another survey.

\section{Methodology}

\subsection{Research Design}

For the purpose of this study, the descriptive cross-sectional survey design was employed. This design allows the collection of data in order to test hypotheses or to answer questions concerning current status of the subjects under study as postulated by Amedahe (2002). For the purpose of generalizing from a sample to a population so that inferences can be made about some characteristics, attitudes, and behaviours of the population, this design has been recommended by Cohen, Manion \& Morrison (2007). Gay (2004, p. 187) posited that "the descriptive survey involves collecting data in order to test hypotheses or to answer research questions concerning the current status of the subject of study". Descriptive survey design was used because the design allows for generalization of findings from sample to population. In descriptive survey a whole lot of information can be collated and gathered on a large and hefty sample within a short time frame with the survey. With descriptive survey large amount of data can be gathered within short period of time. The design has the advantage of evaluating perceptions, attitudes and behaviours in their original happening without external manipulations through recording, coding, analysing and reporting the conditions. The mental well-being, emotional awareness and regulation as well as confidence in one's self in relation to academics is best ascertained by the individuals reporting from their own perspective and understanding. This is confirmed by Best and Khan (2009) when they asserted that conditions of social phenomenon are best studied using survey.

\subsection{Population}

The target population included all public College of Education students in Ghana. The accessible population for the study consisted of level 300 students from two Colleges of Education in Ghana which amount to 822.

\subsection{Sample and Sampling Procedures}

The multi-stage sampling procedures were used in the study. The Colleges of Education in Ghana are in five zones namely Northern Zone, Ashanti/Brong Ahafo Zone, Volta zone, Eastern/Greater Accra Zone and Central/Western zone. The purposive sampling technique was used to select two Colleges of Education from the five zones namely Agona SDA College of Education and Tamale College of Education. After the Colleges of Education has been selected the proportionate sampling technique was used to identify the total number of students to be used from each of the two Colleges selected. After proportionate sampling technique has been used the simple random sampling procedure specifically, the table of random numbers was used select the students to answer the questionnaire. In order to select the sample from the population of Colleges of Education students, the Krejcie and Morgan (1970) sample size determination table was employed. In accordance with Krejcie and Morgan (1970) sample size determination, for a population of 822, it is recommended that a sample of 262 is selected. The return rate collected from the field was 229 which was used as the sample size. 


\subsection{Data Collection Instrument}

The data was collected using the original ASC scale by Liu \&Wang (2005) which measured academic confidence and academic effort on the general academic self-concept. Academic confidence and academic effort served as endogenous variables to the general academic self-concept. The instrument had 20 items on a 6-point scale on which students responded to indicate their agreement or disagreement with the items. The scales ranges from Strongly Disagree- 1, Disagree- 2, Disagree Somewhat- 3, Agree Somewhat- 4, Agree- 5, Strongly Agree6. Students end of term results were used as grade point average (GPA).

\section{Findings}

6.1 Hypothesis 1

H0: ASC will predict academic performance of College of Education students.

The hypothesis sought to establish whether ASC will predict academic performance of College of Education students. The result is presented in Table 1.

Table 1: Linear Regression on Academic Self-Concepts and Academic performance

\begin{tabular}{|c|c|c|c|c|c|}
\hline \multirow[b]{2}{*}{ Model } & \multicolumn{2}{|c|}{ Unstandardized Coefficients } & \multirow{2}{*}{\begin{tabular}{|c} 
Standardized Coefficients \\
Beta
\end{tabular}} & \multirow[b]{2}{*}{$\mathrm{t}$} & \multirow[b]{2}{*}{ Sig. } \\
\hline & $\mathrm{B}$ & Std. Error & & & \\
\hline (Constant) & 213.239 & 10.868 & & 19.621 & .000 \\
\hline Academic self-concepts & .096 & .127 & .050 & .752 & .453 \\
\hline
\end{tabular}

Source: Field Data (Amoah, Acheampong, Sefah, Britwum \& Adjei, 2021)

From Table 1, the results indicates that ASC did not predicts academic performance of College of Education students $(\mathrm{r}=.021,<0.05)$. Also, ASC account for $0.2 \%$ of the variation in the academic performance of students.

\subsection{Hypothesis 2}

H0: There is no statistical significance gender difference in ASC of College of Education students

The hypothesis sought to establish whether there existed differences between male and female students in terms of academic self-concepts. The result is presented in Table 2.

Table 2: Mean difference

\begin{tabular}{|l|l|l|l|l|l|}
\hline Variable & Gender & N & Mean & Std. Deviation & Std. Error Mean \\
\hline Academic & Male & 115 & 206.4609 & 16.43236 & 1.53233 \\
Self-Concept & Female & 114 & 203.7456 & 18.31910 & 1.71574 \\
\hline
\end{tabular}

Source: Field Data (Amoah, Acheampong, Sefah, Britwum \& Adjei, 2021)

Table 2, displays the frequencies, means and standard deviations of the self-reported total academic selfconcept construct between male and female students. The data presented in the table depicts an existence of mean differences between male and female students in terms of their academic self-concept. To test whether these differences in means are statistically significant, Independent Sample T-test was run and the result is presented in Table 3.

Using Leven's test for equality of variation, Table 3 reveals equality of variances test was not significant ( $p>.05)$ therefore the assumption of homogeneity of variances have been met. Hence, Independent Sample T-test was used to evaluate the mean difference between male and female students in relation to total academic selfconcept construct. On the average academic self-concept is higher among male students $(\mathrm{M}=206.4609, \mathrm{SD}=$ 16.43236) than females $(\mathrm{M}=203.7456, \mathrm{SD}=18.31910)$. The difference was not statistically significant $\mathrm{t}(227)=$ $1.181, \mathrm{p}<.05$. However, the eta squared statistic $(.006)$ indicated a small effect size.

Table 3: Independent Sample T-test

\begin{tabular}{|c|c|c|c|c|c|c|c|c|c|c|}
\hline & \multicolumn{2}{|c|}{$\begin{array}{l}\text { Levene's Test } \\
\text { for Equality of } \\
\text { Variances }\end{array}$} & \multicolumn{7}{|c|}{ t-test for Equality of Means } \\
\hline & & \multirow[b]{2}{*}{$\mathrm{F}$} & \multirow[b]{2}{*}{ Sig. } & \multirow[b]{2}{*}{$\mathrm{T}$} & \multirow[b]{2}{*}{ Df } & \multirow{2}{*}{\multicolumn{2}{|c|}{\begin{tabular}{l|l} 
Sig. (2- Mean \\
tailed) & Difference
\end{tabular}}} & \multicolumn{3}{|c|}{\begin{tabular}{l|l}
$95 \%$ Confidence \\
Std. Error \\
Difference
\end{tabular}} \\
\hline & & & & & & & & Difference & Lower & Upper \\
\hline \multirow[t]{2}{*}{$\begin{array}{l}\text { Academic } \\
\text { Self-Concept }\end{array}$} & $\begin{array}{l}\text { Equal } \\
\text { variances } \\
\text { assumed }\end{array}$ & .036 & .849 & 1.181 & 227 & .239 & 2.71526 & 2.29930 & -1.81544 & 2.71361 \\
\hline & \begin{tabular}{|l|} 
Equal \\
variances not \\
assumed
\end{tabular} & & & 1.180 & 223.935 & .239 & 2.71526 & 2.30039 & -1.81792 & 2.70789 \\
\hline
\end{tabular}

Source: Field Data (Amoah, Acheampong, Sefah, Britwum \& Adjei, 2021) 


\section{Discussion of Results}

ASC did not predict academic performance of College of Education students, according to research hypothesis one. The findings of the study are congruent with those of Marsh, Hau, and Kong (2000), who discovered that participating in a high achiever's group in the classroom can increase and reinforce students' ASC. When students are part of a high-achieving group, they adapt the traits of others in the group to better understand and improve their ASC, and as a result, their performance will improve. According to Marsh, Trautwein, Ludtke, Koller, and Baumert (2005), improving students' academic performance without also improving their selfconcept in associated academic subjects would likely yield only short-term benefits. Marsh et al. (2005) proposed this, and Liu (2009) agreed, stating that students with poor academic outcomes are more likely to develop negative academic trust, which can lead to a negative ASC. Again, in order to improve student's selfconcepts teachers may design means of sparking students' interest in learning, demonstrating its relevance, and providing them with feedback in order to raise their expectation of success in the classroom. Teachers can promote students' learning pleasure by being kind and responsive to their needs which will boost students' selfconcepts and lead to better academic performance of students (Allred, \& Cena, 2020).

The second research hypothesis revealed that there is no statistically significant difference in ASC between male and female students. The findings of this study agree with those of Bacon (2011), who discovered that gender has no bearing on ASC. This could also be because, regardless of their self-concepts, both male and female students aspire to higher academic achievement and as a result, work hard in order to succeed.

\section{Conclusion and Recommendations}

Students' ASC did not predict academic performance of College of Education students, according to the research. The study findings also revealed that, there is no statistically significant differences between male and female students. According to the findings, it is recommended that, stakeholders such as teachers and parents must consider a variety of factors that can influence the development of a healthy ASC. and must also encourage, monitor, and supervise students to put in some effort in their studies because effort promotes academic performance. The study again recommends that academicians should hold workshops and seminars to students in developing a stronger self-concept so that they can improve their abilities and lead a successful life in the future. Students with a low academic self-concept may benefit from counseling sessions in order to enhance their academic standing. It may be suggested that curriculum designers pay attention to the relevance of self-concept and create courses that will encourage students to think critically and thoroughly in order to improve their selfconcept.

\section{References}

Allred, J. B., \& Cena, M. E. (2020). Reading motivation in high school: Instructional shifts in student choice and class time. Journal of Adolescent \& Adult Literacy, 64(1), 27-35

Areepattamannil, S., \& Freeman, J. G. (2008). Academic achievement, academic self-concept, and academic motivation of immigrant adolescents in the Greater Toronto Area Secondary Schools. Journal of Advanced Academics, 19(4), 700- 743.

Aronson, J. (2002). Improving academic achievement: Impact of psychological factors on education. San Diego, CA: Academic Press.

Bacon, S. C. (2011). Academic self-concept and academic achievement of African American students transitioning from urban to rural schools. Retrieved from http://www.ir.uiowa.edu

Baran, M., \& Maskan, A. K. (2011). A study of relationships between academic self-concepts, some selected variables and physics course achievement. International Journal of Education, 3, 1-12. Best, W. J., \& Kahn, V. J. (2009). Research in education (10 ed.). New Delhi: PHI Learning Private Limited.

Binder, D. M., Jones, J. G., \& Strowig, R. W. (1970). Non-intellective self-report variables as predictors of scholastic achievement. Journal of Educational Research, 63,364-366.

Block, J., \& Robins, R. W. (1993). A longitudinal study of consistency and change in self-esteem from early adolescence to early adulthood. Child Development, 64, 909-923.

Cohen, L, Manion, L., \& Morrison, K. (2007). Research methods in education. 6th Edition. London: Routledge Farmer.

Cokley, K. (2000a). An investigation of academic self-concept and its relationship to academic achievement in African American college students. Journal of Black Psychology, 26, 148-164.

Cokley, K. (2007). Critical issues in the measurement of ethnic and racial identity: A referendum on the state of the field. Journal of Counseling Psychology, 54, 224-234.

Cooper, K., Krieg, A., \& Brownell, S. (2018). Who perceives they are smarter? Exploring the influence of student characteristics on student academic self-concept in physiology. Advances in Physiology Education, 42(2), 200-208.

Deyhle, D., \& Swisher, K. (1997). Research in American Indian and Alaska Native education: From assimilation 
to self-determination. In M. W. Apple (Ed.), Review of research in education: Vol. 22 (pp. 113-194). Washington, DC: American Educational Research Association

Eurydice, H. (2004). Integrating immigrant children into schools in Europe. Brussels, Germany: Author

Epps, E. G. (1969). Correlates of academic achievement among northern and southern urban Negro students. Journal of Social Issues, 25(3), 55-70.

Fink, M. B. (1997) Self-concept as it relates to academic underachievement. California. Journal of Educational Research, 13, 57-62.

Fuligni, A. J. (1997). The academic achievement of adolescents from immigrant families: The roles of family background, attitudes, and behavior. Child Development, 68, 261-273.

Fuligni, A. J. (2001). Family obligation and the academic motivation of adolescents from Asian, Latin American, and European backgrounds. In A. Fuligni (Ed.), Family obligation and assistance during adolescence: Contextual variations and developmental implications (pp. 61-76). San Francisco: Jossey-Bass.

Fuligni, A. J., \& Fuligni, A. S. (2007). Immigrant families and the educational development of their children. In J. E. Lansford, K. Deater-Deckard, \& M. H. Bornstein (Eds.), Immigrant families in contemporary society: Duke series in child development and public policy (pp. 231-249). New York: Guilford Press.

Green, J., Nelson, G., Martin, A. J., \& Marsh, H. (2006). The causal ordering of self-concept and academic motivation and its effect on academic achievement. International Education Journal, 7(4), 534-546.

Guay, F., Ratelle, C. R., Roy, A., \& Litalien, D. (2010). Academic self-concept, autonomous academic motivation, and academic achievement: Mediating and addictive effects. Learning and Individual Differences, 20, 644-652.

Helmke, A., \& van Aken, M. A. (1995). The causal ordering of academic achievement and self-concept of ability during elementary school. Journal of Educational Psychology, 87(4), 624.

Ireson, J., \& Hallam, S. (2009). Academic self-concepts in adolescence: Relations with achievement and ability grouping in schools. Learning and Instruction 19(3), 13-201.

Jones, J. G. \& Grieneeks, L. (1970). Measures of self-perception as predictors of scholastic achievement. Journal of Educational Research, 63, 201-203

Jones, J. G. \& Strowig, R. W. (1968). Adolescent identity and self-perception as predictors of scholastic achievement. Journal of Educational Research, 62, 78-82

Joppke, C., \& Morawska, E. (2003). Toward assimilation and citizenship: Immigrants in liberal nation-states. New York: Palgrave Macmillan.

Karasakaloğlu, N., \& Saracaloğlu, A. S. (2009). Sınıf öğretmeni adaylarinin türkçe derslerine yönelik tutumları, akademik benlik tasarimlari ile başarı arasındaki ilişki. Yüzüncü Yıl Üniversitesi. Eğitim Fakültesi Dergisi, 6(1), 343-362.

Kubiniec, C. M. (1970). The relative efficacy of various dimensions of the self-concept in predicting academic achievement. American Educational Research Journal, 7, 321-336

Lansford, J. E., Deater-Deckard, K., \& Bornstein, M. H. (2007). Immigrant families in contemporary society: Duke series in child development and public policy. New York: Guilford Press

Lent, R. W., Brown, S. D., \& Gore, P. A. (1997). Discriminant and predictive validity of academic self-concept, academic self-efficacy, and mathematics-specific self-efficacy. Journal of Counseling Psychology, 44, 307315.

Liu, H. (2009). Exploring changes in academic self-concept in ability grouped English classes. change. Journal of Humanities and Social Sciences, 2(2), 411-432.

Liu, W. C., \& Wang, C. K. J. (2005). Academic self-concept: A Cross-Sectional Study of Grade and Gender Differences in a Singapore Secondary School. Asia Pacific Education Review, 6(1), 20-27.

Marsh, H. W. (1986). Global self-esteem: Its relation to specific facets of self-concept and their importance. Journal of Personality and Social Psychology, 51, 1224-1236.

Marsh, H. W. (1990). A multidimensional, hierarchical model of self-concept: Theoretical and empirical justification. Educational Psychology Review, 2, 77-172.

Marsh, H. W., \& Craven, R. (1997). Academic self-concept: Beyond the dustbowl. In G. K. Phye (Ed.) Handbook of classroom assessment, learning, achievement and adjustment (pp. 131-198). Orlando, F.L. Academic Press.

Marsh, H. W., Hau, K.T., \& Kong, C.K. (2000). Multilevel causal ordering of academic self-concept and achievement: Influence of language of instruction (English compared with Chinese) for Hong Kong students. American Educational Research Journal, 39(3), 727-763.

Marsh, H. W., \& Hau, K.-T. (2004). Explaining paradoxical relations between academic self-concepts and achievements: Cross-cultural generalizability of the internal/external frame of reference predictions across 26 countries. Journal of Educational Psychology, 96, 56-67.

Marsh, H. W., \& Parker, J. (1984). Determinants of student self-concept: is it better to be a relatively large fish in a small pond even if you don't learn to swim as well? Journal of Personality and Social Psychology, 47, 


\section{3-231.}

Marsh, H. W., Trautwein, U., Ludtke, O., Koller, O., \& Baumert, J. (2005). Academic self-concept, interest, grades, and standardized test scores: Reciprocal effects models of causal ordering. Child Development, 76, $397-416$.

Marsh, H., \& Seeshing, A. (1997). Causal effects of academic self-concept on academic achievement: structural equation of longitudinal data. Journal of Educational Psychology, 89(1), 41-54.

Marsh, H. W., Trautwein, V., Ludtke, O., Koller, O., \& Baumert, J. (2005). Academic self-concept, interest, grades and standardized test scores: Reciprocal effects models of causal ordering. Child Development, 76(2), $397-416$.

Pehlivan, Z. (2006). Resmi genel liselerde öğrenci devamsızlı̆̆l ve buna dönük okul yönetim politikaları (Ankara ili örneği). The absenteeism at state secondary schools and related school management policies (Ankara Case)]. (Unpublished doctoral thesis), Ankara University, Ankara.

Saani, A. J. (2012). Influence of school organisational culture on public basic school teacher's commitment to the teaching profession. Unpublished master's thesis, University of Cape Coast, Cape Coast.

Schnepf, S. V. (2006). How different are immigrants? A cross-country and cross-survey analysis of educational achievement. In C. Parsons \& T. Smeeding (Eds.), Immigration and the transformation of Europe (pp. 200 234). Cambridge, England: Cambridge University Press.

Skaalvik, E.M., Valas, H., \& Sletta, O. (1994). Task involvement and ego involvement: Relations with academic achievement, academic self-concept and self-esteem. Scandinavian Journal of Educational Research, 38, 231- 243.

Shavelson, R. J., Hubner, J. J., \& Stanton, G. C. (1976). Self-concept: Validation of construct interpretations. Review of Educational Research, 46, 407-441.

Shaw, M. C., \& Alves, G. J. (1963). The self-concept of bright academic underachievers: continued. Personnel and Guidance Journal, 42, 401-403.

Taylor, A., \& Krahn, H. (2005). Resilient teenagers: Explaining the high educational aspirations of visible minority immigrant youth in Canada. Journal of International Migration and Integration, 6, 405-434.

West African Examination Council (2012). General resume of the chief examiners' reports on the standard of the papers. Accra: WAEC Ghana. 